\title{
PERBANDINGAN EFEKTIFITAS METODE ELEKTROKOAGULASI DAN DESTILASI DALAM MENURUNKAN BEBAN PENCEMAR KIMIA PADA AIR LIMBAH DOMESTIK
}

\author{
Muliyadi'), Susan Arba1) \\ Poltekkes Kemenkes Ternate
}

\begin{abstract}
Abstrak
Di negara berkembang seperti Indonesia, pencemaran oleh air limbah domestik merupakan jumlah pencemar terbesar (85\%) yang masuk ke badan air. Sedangkan di negara maju pencemar domestik mencakup $15 \%$ dari seluruh pencemar yang memasuki badan air. Penelitian ini merupakan penelitian eksperimental sederhana dengan rancangan post test only group control design. Penelitian ini dilakukan untuk mengetahui perbandingan efektifitas metode elektrokoagulasi dan destilasi dalam menurunkan beban pencemar kimia pada limbah cair domestic. Populasi dalam penelitian ini adalah seluruh limbah cair yang ada di parit perumahan dagymoi tubo. Sampel dalam penelitian ini adalah 10 liter limbah cair yang ada di parit perumahan dagymoi tubo . teknik pengambilan sampel menggunakan teknik purposive sampling. Dissolved Oxigen pada perlakuan destilasi meningkat sebesar 566,66 \% (6,8 ppm) sedangkan Dissolved Oxigen pada elektrokoagulasi meningkat sebesar 266,67\% (3,2 ppm) dan $\mathrm{pH}$ pada destilasi maupun elektrokoagulasi menjadi netral dengan angka 7. Perlakuan dengan menggunakan destilasi lebih efektif dalam Meningkatkan DO, akan Tetapi sama dalam menetralkan $\mathrm{pH}$.
\end{abstract}

Kata kunci : Destilasi; Elektrokoagulasi; Dissolved Oxigen; $p H$

\begin{abstract}
Comparison of the Effectiveness of Electrocoagulation and Distillation Methods in Reducing Chemical Pollutant Burden in Domestic Wastewater. In developing countries like Indonesia, pollution by domestic wastewater is the largest amount of pollutants (85\%) that enter water bodies. Meanwhile, in developed countries domestic pollutants account for $15 \%$ of all pollutants entering water bodies. This research is a simple experimental study with a post test only group control design. This research was conducted to determine the comparison of the effectiveness of electrocoagulation and distillation methods in reducing the load of chemical pollutants in domestic wastewater. The population in this study were all liquid waste in the ditch of Dagymoi Tubo housing. The sample in this study was 10 liters of liquid waste in the ditch of Dagymoi Tubo housing. The sampling technique used was purposive sampling technique. Dissolved Oxygen in the distillation treatment increased by $566.66 \%$ (6.8 ppm) while Dissolved Oxygen in electrocoagulation increased by $266.67 \%(3.2 \mathrm{ppm})$ and $\mathrm{pH}$ in distillation and electrocoagulation became neutral with a number of 7. Treatment using distillation is more effective in increasing DO, but the same in neutralizing $\mathrm{pH}$
\end{abstract}

Keywords : Distillation; Electrocoagulation; Dissolved Oxygen; $\mathrm{pH}$

Koresponden : Muliyadi

Email : muliyadi.blues90@gmail.com 


\section{Pendahuluan}

Meningkatnya kegiatan manusia akan menimbulkan berbagai masalah, salah satunya tercemarnya air pada sumber-sumber air karena menerima beban pencemaran yang melampaui daya dukungnya. Pencemaran yang mengakibatkan penurunan kualitas air dapat berasal dari limbah terpusat (point sources) dan limbah tersebar (non point sources). Limbah terpusat seperti limbah industri, limbah usaha peternakan, limbah perhotelan, dan limbah rumah sakit. Sedangkan limbah tersebar seperti limbah pertanian, limbah perkebunan dan limbah domestik (Asmadi dan Suharno 2012)

Dampak terhadap kesehatan manusia memang tidak langsung dirasakan tapi akan menimbulkan dampak setelah beberapa tahun. Dengan demikian, pencemaran lingkungan sering kali mengandung berbagai risiko terhadap kesehatan manusia. Beberapa peristiwa pencemaran lingkungan telah memberikan dampak kesehatan bagi manusia dinegara maju,seperti pencemaran merkuri di Teluk Minamata di Jepang serta pencemaran sungai di Kanada. Sedangkan di Indonesia pernah terjadi di Teluk Buyat, Sulawesi Utara akibat limbah merkuri yang diduga dari tambang emas (Rahmadi 2011)

Salah satu metode yang dapat digunakan dalam pengolahan limbah cair adalah metode elektrokoagulasi. Metode elektrokoagulasi merupakan pengembangan dari metode koagulasi yaitu pemisahan zatzat organic dan padatan yang tersuspensi yang terdapat di dalam limbah cair. Dalam penelitian ini, metode elektrokoagulasi menggunakan logam Al sebagai elektroda yang menghasilkan $\mathrm{Al}+$ dan bereaksi dengan zat-zat organik dalam limbah cair. Penggunaan Al sebagai elektroda karena Al bekerja sangat efisien dalam pengolahan limbah cair dan mampu menurunkan kadar polutan. Selain itu, elektroda ini juga memiliki beberapa keunggulan yaitu harganya murah, mudah diperoleh dan memiliki daya korosifitas yang rendah (Ciorba et al. 2000).

Teknik elektrokoagulasi ini sendiri memiliki beberapa keunggulan yaitu peralatan yang digunakan sederhana, mudah dalam pengoperasian, waktu reaksi singkat karena menggunakan sistem mengalir, tidak menghasilkan limbah sekunder karena tidak menggunakan zat kimia. Disamping itu , selama proses elektrokoagulasi kandungan garam tidak bertambah secara signifikan sebagaimana terjadi pada pengolahan secara kimiawi (Mollah et al. 2001).
Destilasi adalah proses pemisahan komponen-komponen suatu campuran yang terdiri atas dua cairan atau lebih berdasarkan perbedaan tekanan uap atau berdasarkan perbedaan titik didih komponen-komponen senyawa tersebut. Proses destilasi dimana uap yang dihasilkan akan menguapkan semua senyawa yang mudah menguap (Fatimura 2014)

Penelitian mengenai efektifitas metode elektrokoagulasi dalam menurunkan beban pencemar pada air limbah domestik telah dilakukan oleh beberpa peneliti sebelumnya seperti pada penelitian agung prabowo, tahun 2012 yang mengemukakan bahwa Secara umum percobaan dengan metode elektrokoagulasi pada skala laboratorium pada kondisi batch, cukup efektif dalam menurunkan kadar pencemar pada air limbah dimana terdapat penyisihan konsentrasi COD tertinggi mencapai $29,83 \%$ terjadi pada menit ke 120 .

Adapun penelitian yang dilakukan oleh (Tambunan dan Edisar 2015) tentang destilasi air laut menggunakan pemanas matahari dengan reflektor cermin cekung menunjukkan bahwa ampel air sebelum dan sesudah destilasi menunjukkan peningkatan mutu kualitas yang sangat signifikan terutama salinitas menurun menjadi 0 setelah didestilasi dari $27,5 \mathrm{ppt}$ sebelum destilasi.

Melihat dari sudut pandang dan beberapa penelitian yang meneliti mengenai pemanfaatan metode destilasi dan elektrokoagulasi sebagai teknologi tepat guna dalam pengolahan limbah cair maka perlu adanya suatu usaha untuk memanfaatkan metode alternatif berupa teknologi tepat guna, yaitu metode yang mampu dan mudah dikerjakan dari bahan yang umum dipakai dalam kehidupan sehari-hari untuk bisa diterapkan secara luas kepada seluruh lapisan masyarakat. Oleh sebab itu perlu dilakukan penelitian lebih lanjut terkait apakah metode elektrokoagulasi dan destilasi mampu menurunkan beban pencemar kimia pada air limbah domestik

\section{Bahan dan Metode}

Jenis penelitian ini merupakan penelitian eksperimental sederhana dengan rancangan post test only group control design.

Populasi dalam penelitian ini adalah seluruh limbah cair yang ada di parit perumahan dagymoi tubo. Sampel dalam penelitian ini adalah 10 liter limbah cair yang ada di parit perumahan dagymoi tubo dengan teknik pengambilan menggunakan teknik purposive sampling pemilihan sampel berdasarkan atas ciri-ciri atau sifat tertentu yang berkaitan dengan karakter populasi dari air limbah. 
Sifat tertentu yang dipakai pada penelitian ini adalah dipakainya sampel air limbah yang langsung dari saluran pembuangan warga agar didapatkan hasil yang representatif.

Pada penelitian ini akan dilakukan ujicoba menggunakan metode elektrokoagulasi untuk menurunkan beban pencemar kimia dengan mengalirkan listrik 12 volt selama 1 jam. Metode destilasi yang digunakan dalam penelitian ini merupakan destilasi sederhana dengan penguapan selama 1 jam dengan rancangan alat yang telah dibuat.
Jenis data dalam penelitian ini yaitu data primer dan data sekunder. Data primer pada penelitian ini adalah hasil pencatatan saat melakukan pengamatan di laboratorium. Data sekunder di peroleh dari literature, buku, serta data-data yang berhubungan dengan metode elektrokoagulasi dan destilasi baik berupa jurnal nasional maupun jurnal internasional.

Pengukuran DO dan $\mathrm{pH}$ dilakukan di labroratorium kampus B Jurusan Kesehatan Lingkungan, dengan menggunakan alat DO Meter dan $\mathrm{pH}$ Meter

\section{Hasil dan Pembahasan}

\begin{tabular}{ccccccc}
\hline \multicolumn{8}{c}{ Perbandingan } \\
\hline Sarameter & Hasil & Satuan & Hasil & satuan & Hasil & satuan \\
DO & 1,2 & ppm & 3,2 & ppm & 6,8 & ppm \\
pH & 6 & - & 7 & - & 7 & - \\
\hline
\end{tabular}

Dari table Tabel 1 menunjukkan bahwa DO (dissolve oxigen) pada sampel limbah cair domestik sebelum perlakuan tidak memenuhi syarat air kelas 3 dimana berdasarkan PP no 82 tahun 2001 harus melebihi 3 ppm sementara hasil uji menunjukkan bahwa DO hanya sebesar 1,2 ppm dan PH (keasaman) pada limbah cair domestic masih dalam kategori memenuhi syarat yang ditetapkan oleh PP no 82 tahun 2001 tentang pengelolaan kualitas air dan pengendalian pencemaran air yaitu 6 akan tetapi masih bisa ditingkatkan ke $\mathrm{Ph}$ netral yaitu 7.

Penelitian ini sejalan dengan penelitian yang dilakukan oleh (Rahmat dan Mallongi 2018) yang menyatakan bahwa Kadar $\mathrm{pH}$ pada air limbah memiliki rata-rata 7,98 dan berdasarkan standar yang telah ditetapkan oleh PP no 82 tahun 2001 masih dalam kategori memenuhi syarat.

Penelitian ini juga sejalan dengan penelitian yang dilakukan oleh (Nilasari, Faizal, dan Suheryanto 2016) yang menyatakan bahwa Nilai $\mathrm{pH}$ air limbah sebagai kontrol atau sebelum diproses dalam penyaringan bertingkat berkisar antara 7,44-7,46 dengan rata-rata sebesar 7,45

Pamungkas, 2016 mengungkapkan bahwa $\mathrm{pH}$ yang tinggi akan mempengaruhi kualitas air di sekitarnya. $\mathrm{pH}$ ini sangat penting sebagai parameter kualitas air karena bisa mengontrol tipe dan laju kecepatan reaksi beberapa bahan di dalam air (Pamungkas 2016) dapat mempengaruhi kehidupan biologi dalam air. Bila terlalu rendah atau terlalu tinggi dapat mematikan kehidupan mikroorganisme. $\mathrm{Ph}$ normal untuk kehidupan air adalah 6-8.(Patria dan Hatmanto 2006)

kondisi $\mathrm{pH}$ juga dapat memengaruhi tingkat toksisitas suatu senyawa kimia,proses biokimiawi perairan, dan proses metabolisme organisme air. Derajat keasaman merupakan faktor yang penting dalam proses pengolahan air untuk perbaikan kualitas air (Djoharam, Riani, dan Yani 2018). Perubahan pH di suatu air sangat berpengaruh terhadap proses fisika, kimia, maupun biologi dari organisme yang hidup di dalamnya. Air yang mempunyai pH 6,7-8,6mendukung populasi makhluk hidup dalam air. Dalam jangkauan itu, pertumbuhan dan perkembangbiakan makhluk hidup air tidak akan terganggu (Purwatiningrum 2018).

Menurut (Purnawan, Warisaura, dan Setyaningrum 2018) Air limbah yang mengandung bahan organik dapat membusuk atau terdegradasi oleh mikroorganisme sehingga bila dibuang ke badan air akan meningkatkan populasi 
mikroorganisme, sehingga akan menaikkan kadar BOD sedangkan sabun akan mengakibatkan naiknya $\mathrm{pH}$ air.

Penelitian ini juga sejalan dengan penelitian yang dilakukan oleh (Gede Ratna Juliasih dan Fadlya Amha 2019) yang menyatakan bahwa Kadar DO pada air limbah sebesar 2,14 mg/L. dimana semakin rendah kadar DO pada air limbah maka semakin buruk kualitas air limbah tersebut yaitu $<3$ ppm. Penelitian ini juga sejalan dengan penelitian yang dilakukan oleh sepriani 2016 yang menyatakan bahwa air sungai yang tercemar limbah memiliki nilai DO sebesar $0,83 \mathrm{mg} / \mathrm{L}$. penelitian ini juga didukung oleh komang dkk, yang menyatakan bahwa terdapat penurunan nilai DO sebesar $11 \%$ pada kondisi air sungai sudah mendapat masukan air limbah Banyaknya lumut akibat eutrofikasi pada area yang diteliti menyebabkan kurangnya DO pada air limbah dan menyebabkan peningkatan COD hal ini seperti yang dijelaskan oleh manihar 2012, yang menyatakan bahwa Kondisi eutrofikasi menyebabkan alga tumbuh dengan cepat akan menutupi permukaan badan air, hingga oksigen terlarut (DO) kurang dari 5 (ppm) menyebabkan kematian biota perairan, badan air jadi anoksik dan berpengaruh terhada kualitas air (Delfanti et al. 2018)

(Ali, Soemarno, dan Purnomo 2013) menyatakan bahwa air yang telah tercemar kandungan oksigennya sangat rendah, makin banyak bahan buangan organik di dalam air makin sedikit sisa kandungan oksigen yang terlarut di dalam air. Penurunan kadar DO ini disebabkan oleh banyaknya zat organik yang dihasilkan dari limbah cair pabrik tahu yang langsung dibuang ke perairan. Rendahnya nilai oksigen terlarut dalam air akan berdampak buruk bagi kehidupan biota yang ada di dalam perairan tersebut.

DO merupakan parameter penting yang dibutuhkan oleh semua organisme, seperti ikan. Penurunan oksigen terlarut dalam perairan akan sangat berbahaya terutama bagi kehidupan akuatik. Kebanyakan ikan pada beberapa perairan tercemar mati bukan karena daya racun bahan buangan secara langsung tetapi karena kekurangan oksigen dalam perairan akibat digunakan untuk proses degradasi bahan organik oleh mikroorganisme (Manalu 2012)

Menurut (Manalu 2012) Oksigen

terlarut (Dissolved Oxygen =DO) dibutuhkan oleh semua jasad hidup untuk pernapasan, proses metabolisme atau pertukaran zat yang kemudian menghasilkan energi untuk pertumbuhan dan pembiakan. Disamping itu, oksigen juga dibutuhkan untuk oksidasi bahanbahan organik dan anorganik dalam proses aerobik. Sumber utama oksigen dalam suatu perairan berasal sari suatu proses difusi dari udara bebas dan hasil fotosintesis organisme yang hidup dalam perairan tersebut. Kecepatan difusi oksigen dari udara, tergantung dari beberapa faktor, seperti kekeruhan air, suhu, salinitas, pergerakan massa air dan udara seperti arus, gelombang dan pasang surut

Menurut (Pratiwi et al. 2019) Kelarutan oksigen pada hasil pengamatan berkisar 2,9-4,8 $\mathrm{mg} / \mathrm{L}$, menunjukkan bahwa kelompok bakteri yang terdapat pada limbah yaitu kelompok bakteri aerobik. Menurut (Wen dan Wei 2011) pada kondisi kelarutan oksigen lebih dari 1 $\mathrm{mg} / \mathrm{L}$, maka bakteri yang terdapat pada limbah yaitu bakteri aerob.

Parameter oksigen terlarutatau DO (Dissolve Oksigen) dapat digunakan sebagai indikator tingkat kesegaran air. Oksigen memegang peranan penting sebagai indikator kualitas perairan, karena oksigen terlarut berperan dalam proses oksidasi dan reduksi bahan organik dan anorganik. Karena proses oksidasi dan reduksi inilah maka peranan oksigen terlarut sangat penting untuk membantu mengurangi beban pencemaran pada perairan secara alami. (Sutriati 2011)

Turunnya DO dalam air akan mempengaruhi kehidupan biota yang ada di dalamnnya, apabila tidak ada kandungan oksigen dalam air maka akan membentuk kondisi anaerobik dengan menimbulkan bau busuk (Ningrum 2018)

Nilai ph pada air hasil elektrokoagulasi dalam penelitian ini sejalan dengan penelitian Suparman yang menyatakan bahwa pada percobaan ke 1 dan ke 2 elektrokoagulasi pada air sungai air hasil elektrokoagulasi mengalami penurunan nilai pH.(Suparman, Rahman, dan Purwoto 2016)

Hal yang sama juga diungkapkan oleh widayanti, yang menyatakan bahwa semakin besar tegangan listrik dan waktu proses elektrolisis, semakin besar pula penurunan TSS dan COD serta $\mathrm{pH}$ semakin netral.(Widayatno T dan Sriyani 2008)

Pada prinsipnya, metoda elektrokoagulasi menerapkan dua buah lempeng elektroda yang dimasukkan kedalam limbah cair yang diolah. Kedua elektroda dialiri arus searah ( $\mathrm{DC}=$ direct current) sehingga terjadi proses elektrokimia. 48 
Susunan rangkaian elektroda dapat diterapkan secara paralel monopolar atau bipolar dengan elektroda bantu. Selain dari itu arus bolak balik ( $\mathrm{AC}=$ alternating current) juga dapat diterapkan (Mollah et al. 2001). Pada penerapan arus DC, reaksi yang terjadi pada anoda adalah oksidasi elektroda. Menurut Ali and Yaakob,(2012), reaksi dapat terjadi sebagai berikut:Pada anode : $\mathrm{Al} \rightarrow \mathrm{Al} 3++$ 3e-Dalam kondisi alkaline terendapkan $\mathrm{Al} 3++3 \mathrm{OH}-$ $\rightarrow \mathrm{Al}(\mathrm{OH}) 3$ Dalam kondisi asam terbentuk oksigen $\mathrm{Al} 3++\quad \mathrm{H} 2 \mathrm{O} \rightarrow \mathrm{Al}(\mathrm{OH}) 3+$ $3 \mathrm{H}+2 \mathrm{H} 2 \mathrm{O} \rightarrow \mathrm{O} 2+4 \mathrm{H}++4 \mathrm{e}-\mathrm{Pada}$ Katoda : $2 \mathrm{H} 2 \mathrm{O}+2 \mathrm{e}-\rightarrow \mathrm{H} 2+2 \mathrm{OH}-$ Dari reaksi tersebut bahwa selama elektrokoagulasi akan terbentuk ion $\mathrm{OH}$-dan ion $\mathrm{H}+$ yang keduanya dapat saling menetralkan atau jika kuantitas keduanya tidak sama akan dapat mengubah $\mathrm{pH}$ larutan. Perubahan $\mathrm{pH}$ larutan dapat menyebabkan laju elektrokoagulasi berubah. Pada $\mathrm{pH}$ tinggi pada umumnya laju elektrokoagulasi meningkat (Vepsäläinen, 2012). Oleh karena itu $\mathrm{pH}$ awal limbah cair yang akan diolah secara elektrokoagulasi sangat penting diperhatikan. Menurut (Vepsäläinen dan Sillanpää 2020), mekanisme elektrokoagulasi secara skematik digambarkan sebagai berikut: Pada anoda pelat logam teroksidasi menghasilkan ion logam dan melepaskan elektron. Ion logam dapat berperan sebagai koagulan. Ion logam selanjutnya dapat mengalami hidrolisis menghasilkan ion logam hidroksida bermuatan yang bertindak sebagai flokulan. Dengan demikian polutan organik dapat mengalami koagulasi dan flokulasi. Pada Katoda, terbentuk gas H2dan juga gas oksigen yang dapat mendorong flokulat mengapung keatas permukaan cairan.

Keberhasilan teknik elektrokoagulasi ditentukan oleh berbagai hal meliputi: jenis elektroda yang digunakan, jarak elektroda, waktu elektrokoagulasi; dan besarnya penerapan voltase dan arus listrik searah, serta jenis dan konsentrasi limbah cair yang diolah. Selama elektrokoagulasi berlangsung terjadi oksidasi pada anoda menghasilkan ion $\mathrm{Al} 3+$, dan ini akan terhidrolisis menghasil- kan ion $\mathrm{H}+$ berdasarkan reaksi:

$\mathrm{Al}(\mathrm{s})) \rightarrow \mathrm{Al}(\mathrm{aq}) 3++3 \mathrm{e}-$

$\mathrm{Al}(\mathrm{aq}) 3++3 \mathrm{H} 2 \mathrm{O} \square \mathrm{Al}(\mathrm{OH}) 3+3 \mathrm{H}+$

Reaksi ini menyebabkan meningkatnya

konsentrasi ion $\mathrm{H}+$ dalam larutan.(Sutanto, Iryani, dan Sarahwati 2018a). Hasil penelitian ini juga sejalan dengan penelitian sutanto 2018 yang menyatakan bahwa Hasil elektrokoagulasi limbah cair pengolahan sagu dapat menaikkan oksigen terlarut dengan pola perubahan peningkatan DO $>5 \mathrm{mg} / \mathrm{L}$. Meningkatnya DO seirama dengan menurunnya TSS dan COD (Sutanto et al. 2018a)

Penelitian ini juga didukung oleh sutanto, 2018 yang menyatakan bahwa Pola perubahan nilai COD selama elektrokoagulasi seirama dengan pola perubahan TSS, yaitu menurun dengan cepat pada menit ke 15 dan selanjutnya terjadi penurunan sangat lambat. . Hal ini disebabkan setelah 15 menit berlangsung jumlah zat organik dalam larutan sudah sangat berkurang, artinya jumlah polutan awal menentukan laju penurunan nilai COD.(Sutanto et al. 2018a)

Penelitian ini juga didukung oleh (Humairoh 2014), yang menyatakan bahwa Kondisi optimum untuk tiap parameter berada pada tegangan 24 volt dan ketinggian elektroda $15 \mathrm{~cm}$ dengan tingkat kontaminan yang dapat meningkatkan nilai DO menjadi 7,77 serta $\mathrm{pH} 8,57$ dalam air sungai Musi.

Berdasarkan penelitian ni made wiratini menyatakan bahwa Hasil pengukuran Lindi setelah proses elektrooksidasi elektrokoagulasi menunjukkan bahwa jarak antar elektroda yang paling efektif mendegradasi lindi yaitu pada jarak $3 \mathrm{~cm}$, dengan nilai DO $3,52 \mathrm{mg} / \mathrm{L}$, COD $428 \mathrm{mg} / \mathrm{L}$, BOD 3,02 $\mathrm{mg} / \mathrm{L}$, absorbansi 0,23, dan $\mathrm{pH} 7,8$.

Berdasarkan penelitian (Amri, Pratiwi Destinefa, dan Zultiniar 2020) juga mempertegas bahwa elektrokoagulasi mampu menjadi media dalam meningkatkan DO dengan mengatakan bahwa pada voltase 12 volt dan kecepatan alir $0,087 \mathrm{~L} / \mathrm{men}$, dengan peningkatan $\mathrm{pH}$ dari 3,6 ke 6,7, penurunan COD sebesar $72,17 \%$ dari $1017 \mathrm{mg} / \mathrm{L}$ ke $283 \mathrm{mg} / \mathrm{L}$, penurunan BOD sebesar $71,53 \%$ dari 513 $\mathrm{mg} / \mathrm{L}$ ke $146 \mathrm{mg} / \mathrm{L}$, serta penurunan TSS sebesar 90,90\% dari $1100 \mathrm{mg} / \mathrm{L}$ ke 100 $\mathrm{mg} / \mathrm{L}$

Oksigen terlarut (DO) meskipun tidak dipersyaratkan dalam baku mutu air limbah tetapi sangat penting diketahui berkaitan dengan jumlah polutan organik dalam air limbah. Semakin banyak jumlah polutan organik, oksigen terlarut semakin sedikit disebabkan oksigen digunakan oleh mikroba untuk mendegradasi limbah. Air jernih dapat mengandung oksigen terlarut mencapai $8 \mathrm{mg} / \mathrm{L}$ tergantung kepada suhuair (Connel \& Miller, 1995). Perairan 
umum yang tidak tercemar mengandung DO >5 mg/L. Hasil elektrokoagulasi limbah cair pengolahan sagu dapat menaikkan oksigen terlarut.(Sutanto, Iryani, dan Sarahwati 2018b)

disimpulkan pada hasil tiga kali percobaan elektrokoagulasi terhadap air sungai dan air waduk nilai TDS pada air hasil elektrokoagulasi mengalami penurunan pada setiap perlakuannya, (Suparman et al. 2016)

Rendahnya DO berhubungan dengan tingginya kadar COD, merepresentasikan tingginya polutan organik dalam sampel. Tingginya kadar TSS mengakibatkan sampel nampak keruh, dan sampel nampak berwarna kuning kemerahan dapat disebabkan oleh adanya zat warna dan kadar besi terlarut.(Sutanto dan Artanti 2019)

Penelitian ini sejalan dengan khusnul khatimah yang menyatakan bahwa Terjadi peningkatan $\mathrm{pH}$ pada waktu distilasi 3 jam menjadi 6,4 dan pada waktu distilasi 4 jam menjadi 7,4.(Husnul Khotimah, Anggraeni, dan Setianingsih 2017)

Adapun penelitian yang dilakukan oleh (Tambunan dan Edisar 2015) tentang destilasi air laut menggunakan pemanas matahari dengan reflector cermin cekung menunjukkan bahwa sampel air sebelum dan sesudah destilasi menunjukkan peningkatan mutu kualitas yang sangat signifikan terutama dimana nilai salinitas menurun ke angka 0 yang sebelumnya mencapai 27,5ppt.

Penelitian (Adani dan Pujiastuti 2018) mengatakan bahwa yang sangat mempengaruhi efiesnsi dari destilasi adalah besarnya koefisien perpindahan panas menyeluruh

Distilasi sederhana adalah teknik pemisahan untuk memisahkan dua atau lebih komponen zat cair yang memiliki perbedaan titik didih yang jauh. Selain perbedaan titik didih, juga perbedaan kevolatilan, yaitu kecenderungan sebuah zat untuk menjadi gas. Distilasi ini dilakukan pada tekanan atmosfer yang normal. Aplikasi distilasi sederhana digunakan untuk memisahkan campuran air dan alkohol. (Wahyudi et al. 2018)

Menurut sutanto, 2018 Meningkatnya DO seirama dengan menurunnya TSS dan COD, jika menilik dari apa yang dikatakan sutanto maka penelitian ini seiring seirama dengan penelitian (Muliyadi dan Sowohy 2020) yang menyatakan bahwa TDS pada perlakuan destilasi menurun sebesar 81,73\% (295 mg/l) dan TSS pada destilasi menurun sebesar 97,7\% (46 mg/l).

Pada proses pemisahan secara distilasi, fase uap akan segera terbentuk setelah sejumlah cairan dipanaskan. Uap dipertahankan kontak dengan sisa cairannya (dalam waktu relatif cukup) dengan harapan pada suhu dan tekanan tertentu, antara uap dan sisa cairan akan berada dalam keseimbangan, sebelum campuran dipisahkan menjadi distilat dan residu. Fase uap yang mengandung lebih banyak komponen yang lebih mudah menguap relatif terhadap fase cair, berarti menunjukkan adanya suatu pemisahan. Sehingga kalau uap yang terbentuk selanjutnya diembunkan dan dipanaskan secara berulang-ulang, maka akhirnya akan diperoleh komponen-komponen dalam keadaan yang relatif murni.(Komariah, Ramdja, dan Leonard 2009)

\section{Simpulan dan Saran}

Nilai rata rata DHL pada sampel 1,2,3 setelah dilakukan destilasi secara berturut-turut adalah $116 \mathrm{mhos} / \mathrm{cm}$ mhos/cm, 109,33 mhos/cm, 109,66 mhos/cm. Nilai rata rata $\mathrm{pH}$ pada sampel 1,2,3 setelah dilakukan destilasi pada semua sampel telah menunjukkan nilai normal dengan rata rata 7 . Terdapat perbedaan nilai DHL sebelum dan sesudah destilasi dengan nilai Sig. (2-tailed) diketahui $<0.005$. Terdapat perbedaan nilai $\mathrm{pH}$ sebelum dan sesudah destilasi dengan nilai Sig. (2-tailed) diketahui $<0.005$

Diharapkan warga kelurahan tubo dapat mengolah limbah sebelum di buang ke lingkungan Diharapkan warga kelurahan tubo dapat memanfaatkan destilasi guna pengolahan limbah cair

\section{Daftar Pustaka}

Adani, Shabrina Iswari Dan Yunita Ali Pujiastuti. 2018. "Pengaruh Suhu Dan Waktu Operasi Pada Proses Destilasi Untuk Pengolahan Aquades Di Fakultas Teknik Universitas Mulawarman.” Jurnal Chemurgy 1(1):31.

Ali, Azwar, Soemarno, Dan Mangku Purnomo. 2013. "Kajian Kualitas Air Dan Status Mutu Air Sungai Metro." Jurnal Bumi Lestari 13(2):265-74.

Amri, Idral, Pratiwi Destinefa, Dan Zultiniar. 2020. "Pengolahan

| H. 50 
Limbah Cair Tahu Menjadi Air Bersih Dengan Metode Elektrokoagulasi Secara Kontinyu." Chempublish Journal 5(1):57-67.

Asmadi Dan Suharno. 2012. Dasar-Dasar Teknologi Pengolahan Air Limbah. Yogyakarta.

Ciorba, George A., Ciprian Radovan, Ilie Vlaicu, Dan Laura Pitulice. 2000. "Correlation Between Organic Component And Electrode Material: Consequences On Removal Of Surfactants From Wastewater." Electrochimica Acta 46(2-3):297-303.

Delfanti, Rachel Dkk. 2018. "Pengolahan Limbah Cair Dengan Elektrokoagulasi Dalam Menurunkan Kadar Fosfat(Po4) Pada Limbah Laundry." Jurnal Sulolipu: Media Komunikasi Sivitas Akademika Dan Masyarakat 372(2):106-12.

Djoharam, Veybi, Etty Riani, Dan Mohamad Yani. 2018. "Analisis Kualitas Air Dan Daya Tampung Beban Pencemaran Sungai Pesanggrahan Di Wilayah Provinsi Dki Jakarta." Jurnal Pengelolaan Sumberdaya Alam Dan Lingkungan (Journal Of Natural Resources And Environmental Management) 8(1):127-33.

Fatimura, Muhrinsyah. 2014. "Jurnal Media Teknik." Jurnal Media Teknik Vol. 11, No.1: 11(1):2331.

Gede Ratna Juliasih, Ni Luh Dan Rian Fadlya Amha. 2019. "Analisis Cod, Do, Kandungan Posfat Dan Nitrogen Limbah Cair Tapioka." Analit: Analytical And Environmental Chemistry 4(01):65-72.

Humairoh, Liza. 2014. "Penerapan Metode Elektrokoagulasi Dalam Penjernihan Air Sungai Musi Menggunakan Elektroda Aluminium.”

Husnul Khotimah, Erika Wulan Anggraeni, Dan Ari Setianingsih. 2017. "Karakterisasi Hasil Pengolahan Air Menggunakan Alat Destilasi Characterization." Journal of
Chemical Information And Modeling 110(9):34-38.

Komariah, Leily Nurul, A. F. Ramdja, Dan Nicky Leonard. 2009. "Tinjauan Toritis Perancangan Kolom Distilasi Untuk Pra-Rencana Pabrik Skala Industri." Jurnal Teknik Kimia 16(4):19-27.

Manalu, Javiter. 2012. "Model Pengelolaan Teluk Youtefa Terpadu Secara Berkelanjutan.”

Mollah, M. Yousuf A., Robert Schennach, Jose R. Parga, Dan David L. Cocke. 2001. "Electrocoagulation ( Ec ) - Science And Applications." Journal Of Hazardous Materials 84:29-41.

Muliyadi, Muliyadi Dan Idayani Sangadji Sowohy. 2020. "Perbandingan Efektifitas Metode Elektrokoagulasi Dan Destilasi Terhadap Penurunan Beban Pencemar Fisik Pada Air Limbah Domestik." Jurnal Kesehatan Lingkungan Indonesia 19(1):45.

Nilasari, E., M. Faizal, Dan S. Suheryanto. 2016. "Pengolahan Air Limbah Rumah Tangga Dengan Menggunakan Proses Gabungan Saringan Bertingkat Dan Bioremediasi Eceng Gondok (Eichornia Crassipes), (Studi Kasus Di Perumahan Griya Mitra 2, Palembang)." Jurnal Penelitian Sains 18(1):168089.

Ningrum, Susanti Oktavia. 2018. "Analisis Kualitas Badan Air Dan Kualitas Air Sumur Di Sekitar Pabrik Gula Rejo Agung Baru Kota Madiun." Jurnal Kesehatan Lingkungan 10(1):1-12.

Pamungkas, M. T. Oktafeni Atur. 2016. "Volume 4, Nomor 2, April 2016." Jurnal Kesehatan Masyarakat 4(April):166-75.

Patria, Bima Dan Dwi Hatmanto. 2006. "Analisis Teknologi Pengolahan Limbah Cair Pada Industri Tekstil (Studi Kasus Pt. Iskandar Indah Printing Textile Surakarta)." Analisis Teknologi Pengolahan Limbah Cair Pada Industri Tekstil (Studi Kasus Pt. Iskandar Indah Printing Textile Surakarta) 1(1):1-6. 
Pratiwi, N. T. M., S. Hariyadi, I. P. Ayu, T. Apriadi, A. Iswantari, Dan D. Y. Wulandari. 2019. "Pengelolaan Kandungan Bahan Organik Pada Limbah Cair Laboratorium Proling - Msp - Ipb Dengan Berbagai Kombinasi Agen Bioremediasi ( Management Of Organic Matter Content From Proling Laboratory Waste Water Using Several Combinations Of Bioremediation Agent." 2019 15(1):89-95.

Purnawan, Angge Dhevi Warisaura, Dan Agnes Setyaningrum. 2018. "Vol . 11 No . 1 Agustus 2018 Issn: 1979-8415 Pengolahan Limbah Cair Rumah Makan Dengan Sistem Vol . 11 No . 1 Agustus 2018 Issn: 1979-8415." Jurnal Teknologi Technoscientia 11(1):47-53.

Purwatiningrum, Oktina. 2018. "Gambaran Instalasi Pengolahan Air Limbah Domestik Komunal Di Kelurahan Simikerto, Kecamatan Simokerto, Kota Surabaya." Jurnal Kesehatan Lingkungan 10(82):243-53.

Rahmadi, Takdir. 2011. Mediasi Penyelesaian Sengketa Melalui Pendekatan Mufakat. Jakarta.

Rahmat, B. Dan Anwar Mallongi. 2018. "Studi Karakteristik Dan Kualitas Bod Dan Cod Limbah Cair Rumah Sakit Umum Daerah Lanto Dg. Pasewang Kabupaten Jeneponto." Jurnal Nasional Ilmu Kesehatan 1(69):1-16.

Suparman, Agus Rahman, Dan Harsunu Purwoto. 2016. "Penggunaan Metode Elektrokoagulasi Sebagai Alternatif Pengolahan Air Bersih Tanpa Bahan Kimia Suparman, Agus Rahman, Harsunu Purwoto." Jurnal Agroteknose Vii(2):46-59.

Sutanto Dan Kareina Artanti. 2019. "Pengolahan Limbah Cair Kosmetik Secara Elektrokoagulasi Sistem Batch." Ekologia 19(2):44-54.

Sutanto, Ani Iryani, Dan Sarahwati. 2018a. "Efisiensi Dan Efektifitas Serta Kinetika Elektrokoagulasi Pengolahan Limbah Sagu Aren." Ekologia 18(1):10-16.
Sutanto, Ani Iryani, Dan Sarahwati. 2018b. "Efisiensi Dan Efektifitas Serta Kinetika Elektrokoagulasi Pengolahan Limbah Sagu Aren." Ekologia 18(1):10-16.

Sutriati, Armaita. 2011. "Penilaian Kualitas Air Sungai Dan Potensi Pemanfaatannya Studi Kasus : S. Cimanuk." Jurnal Sumber Daya Air 7(1):1-17.

Tambunan, Fanrico Sanjaya Dan Muhammad Edisar. 2015. "Destilasi Air Laut Menggunakan Pemanas Matahari Dengan Reflektor Cermin Cekung Pendahuluan Krisis Air Tawar Untuk Air Minum Biasanya Dialami Oleh Sebagian Besar Masyarakat Pesisir, Terutama Di Pulau-Pulau Kecil Dan Terpencil . Sebagian Besar Air Di Bumi." Jurnal Fisika 2(1):116-22.

Vepsäläinen, Mikko Dan Mika Sillanpää. 2020. Electrocoagulation In The Treatment Of Industrial Waters And Wastewaters.

Wahyudi, Nugroho Tri, Faris Faruqi Ilham, Irwan Kurniawan, Dan Ari Susandy Sanjaya. 2018. "Rancangan Alat Distilasi Untuk Menghasilkan Kondensat Dengan Metode Distilasi Satu Tingkat." Jurnal Chemurgy 1(2):30.

Wen, Yi Dan Chao Hai Wei. 2011. "Heterotrophic Nitrification And Aerobic Denitrification Bacterium Isolated From Anaerobic/Anoxic/Oxic Treatment System." African Journal of Biotechnology 10(36):6985-90.

Widayatno T Dan Sriyani. 2008. "Pengolahan Limbah Cair Industri Tapioka Dengan Menggunakan Metode Elektroflokulasi." Prosiding Seminar Nasional Teknoin 2008 Bidang Teknik Kimia Dan Tekstil Mengandung 84-89. 